\title{
Renal Hypertrophy in Experimental Diabetes: Relation to Severity of Diabetes
}

\author{
K. Seyer-Hansen \\ Second University Clinic of Internal Medicine, Kommunehospitalet, Aarhus, Denmark
}

Summary. Streptozotocin diabetic rats have larger kidneys than non-diabetic rats. In the present study the rate of kidney growth during the first seven days of diabetes was correlated with the blood glucose concentration. Over a wide range of blood glucose concentrations $(116-340 \mathrm{mg} / 100 \mathrm{ml})$ the kidney weight, protein content and protein/DNA ratio were closely correlated with the glucose values.

Key words: Blood glucose, diabetes, DNA, hypertrophy, kidney, rat, streptozotocin.

Large kidneys are found in diabetic patients shortly after the clinical appearance of the disease [1], and in rats with streptozotocin diabetes enlargement of the kidneys can be demonstrated as early as $48 \mathrm{~h}$ after the onset of glycosuria [2]. The present study was undertaken to find out whether the magnitude of kidney growth in diabetic rats is dependent on the degree of metabolic derangement.

\section{Methods}

Female Wistar rats weighing 240-260 g were made diabetic by the intraperitoneal injection of streptozotocin $(40-80 \mathrm{mg} / \mathrm{kg})$. Control rats received no injections. Six days after the streptozotocin the rats were placed in metabolic cages for collection of urine. Throughout the whole experiment the animals had free access to food and water. After $24 \mathrm{~h}$ in the metabolic cages (and seven days after streptozotocin) the rats were anaesthesized with pentobarbital $(40 \mathrm{mg} / \mathrm{kg})$. A blood sample was drawn from the tail for blood glucose determination, and the left kidney was quickly excised.
The excised kidney was immediately cooled in icecold saline $(0.154 \mathrm{mmol} / \mathrm{l})$, blotted dry, trimmed free of fat and capsule, weighed, and homogenized in approximately $10 \mathrm{ml}$ of icecold water. The homogenate was brought to $20 \mathrm{ml}$ in a volumetric flask, and aliquots of $5 \mathrm{ml}$ were stored at $-20^{\circ}$.

Blood glucose was determined with Dextrostix ${ }^{\circledR}$ employing a Reflectance Meter (Ames Co.). Urinary glucose was determined with para-toluidin. The nucleic acids in the kidney homogenate were separated by the Schmidt-Tannhäuser method according to Munro and Fleck [3], and the DNA concentration was measured with diphenylamine according to Burton [4]. The protein concentration of the kidney homogenate was determined according to Lowry et al. [5] with bovine albumin as standard.

\section{Statistics}

Grouped data (Table 2) were compared by means of Student's t-test after testing for normal distribution

Table 1. Results of regression analysis of the relation between glucose concentration and kidney weight, protein content, DNA content, protein/DNA and 24-h glucose excretion. For explanation of the significance levels, see text

\begin{tabular}{|c|c|c|c|c|}
\hline $\mathrm{x}$ & $y$ & Equation & $\mathbf{r}$ & $2 \mathrm{p}$ \\
\hline $\begin{array}{l}\text { blood glucose } \\
(\mathrm{mg} / 100 \mathrm{ml})\end{array}$ & $\begin{array}{l}\text { kidney weight } \\
\text { (mg) }\end{array}$ & $y=1.2 x+610$ & 0.82 & $<<0.001$ \\
\hline- & $\begin{array}{l}\text { protein content } \\
\text { (mg) }\end{array}$ & $y=0.12 x+84$ & 0.74 & $<<0.001$ \\
\hline- & $\begin{array}{l}\text { DNA content } \\
(\mathrm{mg})\end{array}$ & $y=0.0008 x+4$ & 0.16 & N.S \\
\hline- & $\begin{array}{l}\text { protein/DNA } \\
(\mathrm{mg} / \mathrm{mg})\end{array}$ & $y=0.02 x+21$ & 0.78 & $<<0.001$ \\
\hline- & $\begin{array}{l}\text { urinary glucose } \\
(\mathrm{g} / 24 \mathrm{~h})\end{array}$ & $y=0.05 x-6$ & 0.80 & $<<0.001$ \\
\hline
\end{tabular}


Table 2. Kidney weight, protein and DNA content and 24-h glucose excretion in non-diabetic rats, and in rats with varying degree of diabetes, grouped according to blood glucose. Results are mean values \pm SEM. 2 p denotes the level of significance of the difference from the control rats

\begin{tabular}{|c|c|c|c|c|c|c|}
\hline $\begin{array}{l}\text { Blood glucose } \\
\text { (mg/100 ml) }\end{array}$ & $\mathrm{n}$ & $\begin{array}{l}\text { Kidney weight } \\
\text { (mg) }\end{array}$ & $\begin{array}{l}\text { Protein } \\
\text { (mg) }\end{array}$ & $\begin{array}{l}\text { DNA } \\
(\mathrm{mg})\end{array}$ & $\begin{array}{l}\text { Protein/DNA } \\
\text { (mg/mg) }\end{array}$ & $\begin{array}{l}\text { Urinary glucose } \\
(\mathrm{g} / 24 \mathrm{~h})\end{array}$ \\
\hline $\begin{array}{l}\leqslant 105 \\
\text { (controls) }\end{array}$ & 10 & $733 \pm 20$ & $97 \pm 2$ & $4.08 \pm 0.09$ & $23.9 \pm 0.4$ & $0.13 \pm 0.02$ \\
\hline $116-150$ & 7 & $773 \pm 18$ & $99 \pm 2$ & $4.10 \pm 0.16$ & $24.4 \pm 0.6$ & $0.88 \pm 0.68$ \\
\hline $151-200$ & 5 & $809 \pm 33$ & $106 \pm 5$ & $4.09 \pm 0.17$ & $25.7 \pm 0.3$ & $2.3 \pm 0.5$ \\
\hline $2 p$ & & 0.06 & 0.08 & & 0.02 & \\
\hline $201-300$ & 6 & $915 \pm 24$ & $116 \pm 4$ & $4.18 \pm 0.21$ & $27.8 \pm 0.8$ & $6.0 \pm 1.6$ \\
\hline $2 p$ & & 0.00006 & 0.0005 & 0.6 & 0.0003 & \\
\hline$>300$ & 10 & $1012 \pm 27$ & $125 \pm 3$ & $4.30 \pm 0.13$ & $29.1 \pm 0.7$ & $11.3 \pm 1.5$ \\
\hline $2 p$ & & 0.0000002 & 0.000001 & 0.2 & 0.000005 & \\
\hline
\end{tabular}

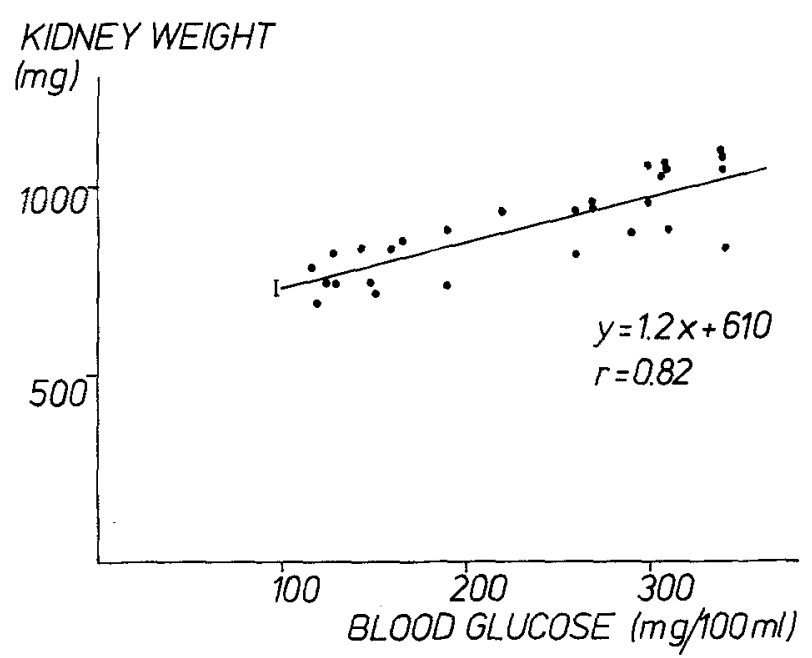

Fig. 1. Kidney weight in diabetic rats as a function of blood glucose concentration. The bar to the left indicates the kidney weight of non-diabetic rats $( \pm$ SEM)

and variance homogeneity. In the correlation analysis (Table 1 ) only approximate $\mathrm{p}$-values are given. This is because the blood glucose values deviate from normal distribution. However, when the data are treated as if they were normally distributed, $\mathrm{p}$ values emerge, which are all below 0.000001 . One can therefore be confident in the levels of significance shown in the table. A non-parametric test has not been chosen because of the importance of stressing the obvious linearity of the correlation.

\section{Results}

All the non-injected rats had blood glucose concentrations below $105 \mathrm{mg} / 100 \mathrm{ml}$. A blood glucose concentration of $115 \mathrm{mg} / 100 \mathrm{ml}$ or more was therefore chosen as indicative of diabetes. According to this definition two of the thirty rats given strep- tozotocin were non-diabetic and were excluded from the study. The remaining 28 diabetic rats had blood glucose concentrations ranging from 116 to 340 $\mathrm{mg} / 100 \mathrm{ml}$ and urinary glucose output from 0.1 to $16 \mathrm{~g} / 24 \mathrm{~h}$.

The figure shows the relation between the blood glucose concentration after seven days of diabetes and the weight of the left kidney. The correlation is obvious, and from Table 1 it can be seen that there was a similar correlation between the blood glucose concentration and the protein content of the kidney. The DNA content, which reflects the number of cells, was not correlated with the blood glucose, but the protein/DNA ratio, which is an expression of the average cell size, showed a close correlation with the blood glucose concentration.

To get an impression of the critical level of metabolic aberration, where a change of kidney size was demonstrable, the rats were divided into groups according to their blood glucose concentration, and mean values of the variables computed (Table 2). A steady rise in all values except DNA was seen. For the rats with the slightest degree of diabetes no statistically significant differences from the control animals were found. When the blood glucose concentration was between 150 and $200 \mathrm{mg} / 100 \mathrm{ml}$, the protein/DNA ratio was significantly higher than in the non-diabetic rats, and at higher blood glucose concentrations kidney weight and protein content were also clearly increased. The DNA content of the kidney showed a tendency to increase with the severest degree of diabetes.

\section{Discussion}

In a recent paper the renal hypertrophy in diabetic rats and its time-course have been described [2]. The process was demonstrable after $24 \mathrm{~h}$ of glycos- 
uria by a rise in the RNA/DNA ratio and in the RNA content of the kidney. After 8 days there was a significant increase in the DNA content, and renal growth continued as a combination of hypertrophy and hyperplasia. In that study all the rats had blood glucose concentrations exceeding $350 \mathrm{mg} / 100 \mathrm{ml}$.

The present study, involving a spectrum of degrees of diabetes with blood glucose below 350 $\mathrm{mg} / 100 \mathrm{ml}$, demonstrates a close correlation between the degree of metabolic derangement and the rate of growth of the hypertrophying kidney during the first seven days of diabetes. Figure 1 and Table 2 show a steady rise in the variables over the whole range of blood glucose concentrations.

In previous studies [2] it was shown, that the growth of the diabetic kidney continues for much longer than the first week of diabetes, probably for at least one month. The results presented here, therefore, do not indicate whether the slower renal growth in slight hyperglycaemia will lead to an endstage different from that in severe diabetes, or whether the process will just take a longer time.

The relationship between the early renal changes in diabetic humans [1] and rats and the glomerulosclerosis in long-term diabetes is not clear. It is possible that lesions of the kind described here are in some way the initial stage of glomerulosclerosis. The finding of a close correlation between metabolic derangement and kidney hypertrophy fits well with the general belief that diabetic angiopathy, including nephropathy, is a result of the not completely normalized metabolism during the life of the diabetic patient.
It is, of course, also possible that the kidney lesions are due solely to the greater osmotic load and not to diabetes per se. Further studies are being undertaken to clarify this point.

Acknowledgements. I am grateful to Mrs. Joan Hansen for excellent technical assistance. The work was supported by Statens lægevidenskabelige Forskningsråd.

\section{References}

1. Mogensen, C. E., Andersen, M. J. F.: Increased kidney size and glomerular filtration rate in untreated juvenile diabetes: normalization by insulin treatment. Diabetologia 11, 221-224 (1975)

2. Seyer-Hansen, K.: Renal hypertrophy in streptozotocin diabetic rats. Clin. Sci. Mol. Med. 51, 551-555 (1976)

3. Munro, H.N., Fleck, A.: The determination of nucleic acids. Methods Biochem. Anal. 14, 113-176 (1966)

4. Burton, K.: A study of the conditions and mechanism of the diphenylamine reaction for the colorimetric estimation of deoxyribonucleic acid. Biochem. J. 62, 315-323 (1956)

5. Lowry, O.H., Rosebrough, N.J., Farr, A.L., Randell, R.J.: Protein measurement with the Folin phenol reagent. J. Biol. Chem. 193, 265-271 (1951)

Received: August 31, 1976, and in revised form:

December 28, 1976

Dr. K. Seyer-Hansen

Dept. of Medicine

Aarhus Kommunehospital

DK-8000 Aarhus C

Denmark 